\title{
COMBINED EFFECTS OF WARMING AND SHADING ON GROWTH AND PHOTOSYNTHETIC PERFORMANCE OF SUBMERGED MACROPHYTES FROM SONGKHLA LAGOON, THAILAND
}

\author{
Chotikarn, P. ${ }^{1,2,3}$ - Kaewchana, P. ${ }^{2,3}$ - Roekngandee, P. ${ }^{2,3}$ - Pramneechote, P. $^{3}$ - \\ PRATHEP, A. ${ }^{4}-$ SINUTOK, S. ${ }^{2,3^{*}}$ \\ ${ }^{I}$ Marine and Coastal Resources Institute, Faculty of Environmental Management, Prince of \\ Songkla University, Hat Yai, Thailand \\ ${ }^{2}$ Faculty of Environmental Management, Prince of Songkla University, Hat Yai, Thailand \\ ${ }^{3}$ Coastal Oceanography and Climate Change Research Center, Prince of Songkla University, \\ Hat Yai, Thailand \\ ${ }^{4}$ Seaweed and Seagrass Research Unit, Excellence Center for Biodiversity of Peninsular \\ Thailand, Division of Biological Science, Faculty of Science, Prince of Songkla University, Hat \\ Yai, Thailand \\ Corresponding author \\ e-mail:ssutinee@gmail.com \\ (Received 23 ${ }^{\text {rd }}$ Feb 2021; accepted $14^{\text {th }}$ May 2021)
}

\begin{abstract}
Macrophytes play an important role in maintaining high physical and biological diversity in freshwater ecosystems. However, during the past several centuries since the industrial revolution, human activities and climate change have caused significant changes in the structure and function of aquatic environments, for example via increased temperature or high sedimentation that reduces light penetration. This study investigated the combined effects of elevated temperature and low light on growth and photosynthetic performance of submerged macrophytes Ceratophyllum demersum and Elodea canadensis and identified temperature and light thresholds for these species. Photosynthetic performance, chlorophyll $a$ and $b$ concentrations, organic and carbon contents, and growth rates were estimated in these two dominant macrophytes sampled from the middle of Songkhla lagoon, subjected to 9 treatments ( 3 light intensities and 3 temperatures) for 9 weeks. The results show that photosynthetic performance according to the indicators EQY, $\alpha$ and $\mathrm{rETR}_{\max }$ was inhibited by low light in both species. C. demersum was more tolerant to temperature and light stresses. This study provides an understanding of physiological tolerance and response to light and temperature stresses, and improves the understanding of how aquatic macrophytes respond to future climatic and anthropogenic changes, supporting the development of sustainable lagoon management plans.
\end{abstract}

Keywords: climate change, organic carbon, PAM fluorometry, chlorophyll, shading

\section{Introduction}

During the past several centuries since the industrial revolution, human activities such as industrialization, urbanization and intensive agriculture activities have caused strong changes in the structure and function of nearby aquatic environments (Smith et al., 1999). The growth of human population has increased the pressure on both aquatic and terrestrial ecosystems causing land transformation and altering hydrological processes and geochemical cycles of carbon (C), nitrogen (N) and phosphorus (P) (Vitousek et al., 1997; Smith et al., 1999). Land transformation and altering hydrological process led to soil erosion and sedimentation in the waterways and in lakes (Pradit et al., 2010). High 
turbidity from sediment load affects vertical light penetration, which leads to low-light conditions and disrupts ecosystem functions (Mi et al., 2019). Furthermore, the anthropogenic release of greenhouse gases into the atmosphere, predominantly carbon dioxide $\left(\mathrm{CO}_{2}\right)$, has led to increased global temperatures through the trapping of heat in the Greenhouse Effect. As a consequence, surface water temperature has increased and is predicted to increase in the future. Climate change is expected to have profound impacts to terrestrial and aquatic ecosystems and their resident organisms (Johnson et al., 2007).

Macrophytes play an important role in maintaining high physical and biological diversity and act as ecosystem engineers ( $\mathrm{Li}$ et al., 2018) that provide nutrient cycling capacity, and also act as habitat structure and refugia for aquatic organisms (Wigand et al., 2000; Qiu et al., 2001; Cronk and Fennessy, 2016). Macrophytes are potentially used as powerful natural tools for water quality improvement in lakes and reservoirs due to their capacity in nutrient uptake and in preventing phytoplankton blooms (Liu et al., 2000; Lone et al., 2014). The growth and photosynthesis of submerged macrophytes can be affected by temperature (Chalanika De Silva and Asaeda, 2017), light (Chen et al., 2016), and high organic loads in sediments (Barko and Smart, 1983) due to several coupled biological, physical and chemical modifications of the benthic system (Sand-Jensen et al., 2005; Raun et al., 2010). Diurnal light changes affect photosynthetic activities, and Jiang et al. (2018) found that the Maximum Quantum Yield of photosystem II (MQY) of six common submerged macrophytes decreased at midday under ambient light, but there was no significant change under shade, and MQY was negatively correlated with photon radiance, except for Ceratophyllum demersum, which probably could support high light levels.

Light is a major environmental factor influencing photosynthetic organisms (Hanelt, 1992). Light penetration through a water column is influenced by several factors including depth, suspended particles, and dissolved compounds. A high load of suspended particles can reduce light transmission to photosynthetically active leaf surfaces (Reitsema et al., 2018) and alter gas and nutrient exchanges in submerged macrophytes (Korschgen et al., 1997). Chen et al. (2016) found that Potamogeton maackianus and Vallisneria natans increased their initial slope of RLC $(\alpha)$ and decreased their minimum saturating irradiance $\left(\mathrm{E}_{\mathrm{k}}\right)$ and maximum relative electron transport rate $\left(\mathrm{ETR}_{\mathrm{m}}\right)$ under low light stress, while higher Relative Growth Rate of P. maackianus than $V$. natans was seen with a stronger light intensity but it was decreased in a low light intensity. Shading caused a decrease in net photosynthesis in Chara aspera and Chara canescens within 24 hours, but their photosynthetic performances recovered within a short period, suggesting that these charophytes are able to adapt to low light conditions (Kovtun-Kante et al., 2014). In contrast, increasing irradiance in oligotrophic lake can lead to an increase in photosynthesis, oxygen production and growth rate of macrophytes (Eller et al., 2015). An increase in shoot density and biomass of Vallisneria americana was observed on increasing light intensity from 100 to $600 \mu \mathrm{mol}$ photons $\mathrm{m}^{-2} \mathrm{~s}^{-1}$ (Barko et al., 1984). However, exposure to a high level of light at a shallow depth can lead to a loss of photosynthetic activity through light-dependent down-regulation of photosynthesis, or a rise in photoinhibition and photodamage, which further inhibits growth (Jin et al., 2020).

Many studies have shown that an increase in global temperature influences the health and survivorship of aquatic organisms (Eissa and Zaki, 2011). Each species responds differently in terms of growth, photosynthesis, reproduction and survivorship to global warming (Gonzalez, 2010; Eissa and Zaki, 2011). Temperature influences the 
physiological processes, including photosynthesis and biomass growth rate of macrophytes (Atta-Boateng et al., 2019). Thermal stress can reduce shoot elongation and increase hydrogen peroxide $\left(\mathrm{H}_{2} \mathrm{O}_{2}\right)$ level, damaging photosynthetic pigments and cell membrane structures (Chalanika De Silva and Asaeda, 2018), and may result in shifts in distribution and abundance (Fernández et al., 2020; Miller et al., 2020). Barko and Smart (1981) found that aboveground biomass of submerged macrophytes increased with temperature. However, a recent study showed a decrease in biomass under increasing temperature alone, while an increase in temperature with elevated $\mathrm{CO}_{2}$ increased photosynthetic performance and growth of $V$. natans (Cao and Ruan, 2015).

Songkhla Lagoon is a tropical estuarine lagoon system located on the eastern side of the southern Thai peninsula, and consists of four interconnected water bodies: Thale Noi, upper lagoon, middle lagoon, and lower lagoon (Pongpiachan et al., 2019). Songkhla Lagoon not only supports biodiversity, but also a large number of people whose livelihoods depend on that biodiversity via fishery, aquaculture and tourism (Community Development Department, 2009). Songkhla Lagoon is currently experiencing serious water pollution and sedimentation due to human activities (Pradit et al., 2010; Somboonsuke et al., 2018). This could lead to losing their valuable ecosystem services and functions such as carbon sequestration. The submerged macrophytes found in Songkhla Lagoon include Ceratophyllum demersum, Cladophora sp., Najas malesiana, Najas marina, Najas graminea, Hydrilla verticillata, and Potamogeton malaianus (Thongkao et al., 2001). Climate change is likely to affect each organism in each system differently due to interactions with other factors such as nutrient loading and light. Moreover, studies on effects of light and temperature on growth and photosynthesis of submerged macrophytes in a tropical estuarine lagoon system (like the Songkhla Lagoon) are still lacking. Hence, it is essential to consider the effects of climate change together with low light to successfully manage the eutrophic lagoon (Howarth et al., 2000; Yang et al., 2008).

This study aims to investigate the combined effects of elevated temperature and low light on growth and photosynthesis of submerged macrophytes $C$. demersum and E. canadensis and sought to identify temperature and light thresholds for these species. An understanding of physiological tolerance and response to light and temperature stresses is critical for identifying the main driver for growth photosynthesis and carbon capture potential of submerged macrophytes, and for predicting their performances under these stresses. Furthermore, this study could contribute to understanding how aquatic macrophytes will respond to future climatic and anthropogenic changes in temperature and light, and support the development of sustainable lagoon management plans.

\section{Materials and Methods}

\section{Sample collection and experimental design}

Samples of Ceratophyllum demersum and Elodea canadensis (Fig. 1) were randomly collected from the middle of Songkhla Lagoon (7 $7^{\circ} 28^{\prime} 09.0^{\prime}$ ' N, 100 $23^{\prime} 45.0^{\prime \prime}$ E) (Fig. 2) in May 2018 and were maintained in an aquarium $(50 \mathrm{~L})$ at $30^{\circ} \mathrm{C}, 180 \mu \mathrm{mol}$ photons $\mathrm{m}^{-2} \mathrm{~s}^{-1}$ on a $12 \mathrm{~h}: 12 \mathrm{~h}$ light: dark cycle for 2 weeks of acclimation. Then, samples $(n=4)$ were allocated to 9 controlled aquariums set to three light regimes: 180 (control), $90\left(50 \%\right.$ shading) and $45(75 \%$ shading $) \mu \mathrm{mol}$ photons $\mathrm{m}^{-2} \mathrm{~s}^{-1}$ and three temperatures $\left(30^{\circ} \mathrm{C}\right.$ (control), $33^{\circ} \mathrm{C}$ (RCP4.5 Scenario at year 2046-2065), and $36^{\circ} \mathrm{C}$ (RCP8.5 
Intergovernmental Panel on Climate Change, 2013)) for 9 weeks (Table 1). Temperature and light for each treatment were controlled with water heater (Eheim, Germany) and LED lights (Chihiros, China, 400-700 nm), respectively. Water change (20\%) to each aquarium were done weekly with deionized water: Hoagland solution (9:1). Nitrate and phosphate concentration were tested with Nitrate test kit (API, USA) and phosphate test kit (API, USA). Other water quality parameters such as dissolved oxygen and $\mathrm{pH}$ were measured weekly by YSI Pro Plus multiparameter meter (YSI Inc. / Xylem Inc, USA). Pigment concentration, growth and organic and carbon contents were weekly assessed at initial time (Week 0) and at the end of the experiment (Week 9). Photosynthetic performances were assessed every week from the start to the end of the experiment.
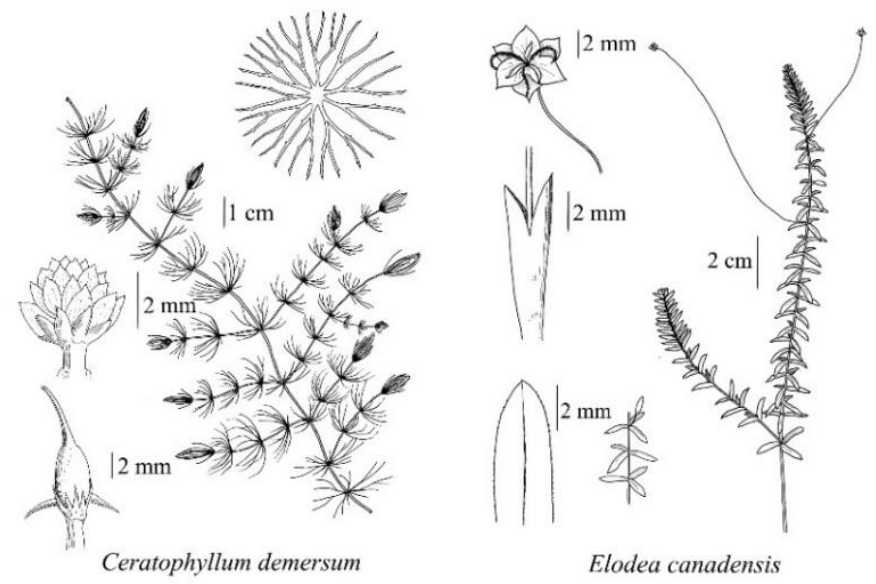

Figure 1. Drawings of Ceratophyllum demersum (left) and Elodea canadensis (right)

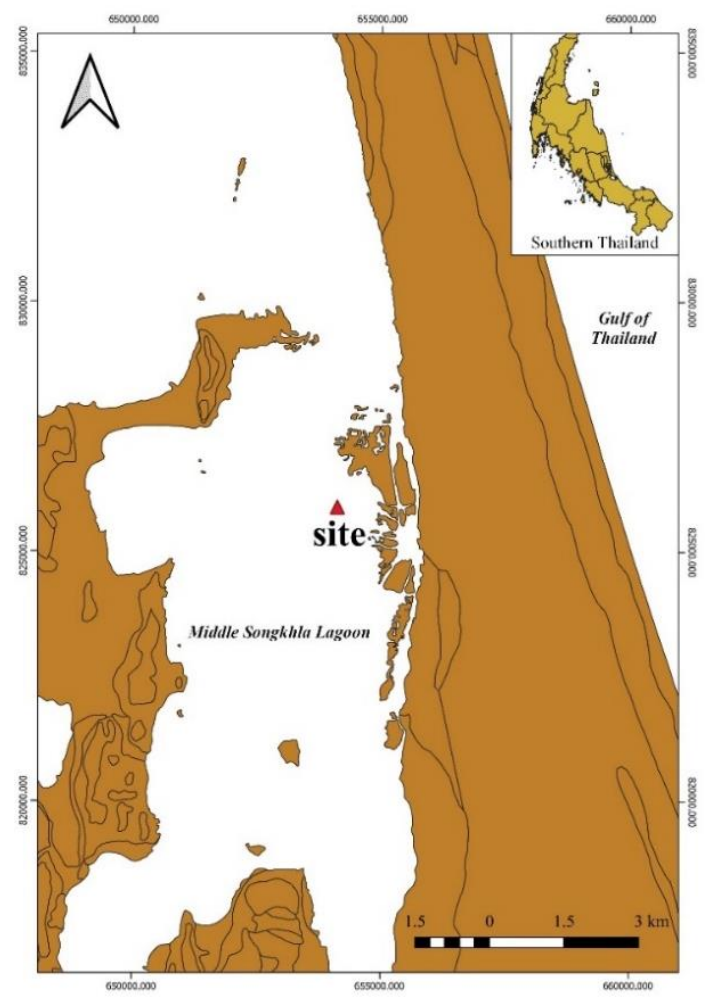

Figure 2. The study site at the middle of Songkhla Lagoon in peninsular Thailand 
Table 1. Experimental design for each treatment and abbreviations

\begin{tabular}{l|c|c|c|c}
\hline \multicolumn{2}{c|}{} & \multicolumn{3}{|c}{ Light intensity $\left(\boldsymbol{\mu m o l}\right.$ photons $\left.\mathbf{~ m}^{-2} \mathbf{s}^{-\mathbf{1}}\right)$} \\
\cline { 3 - 5 } \multicolumn{2}{c|}{} & $\mathbf{1 8 0}$ & $\mathbf{9 0}$ & $\mathbf{4 5}$ \\
\hline \multirow{3}{*}{ Temperature $\left({ }^{\circ} \mathbf{C}\right)$} & $\mathbf{3 0}$ & T30L180 & T30L90 & T30L45 \\
& $\mathbf{3 3}$ & T33L180 & T33L90 & T33L45 \\
& $\mathbf{3 6}$ & T36L180 & T36L90 & T36L45 \\
\hline
\end{tabular}

\section{Photosynthetic activity}

Photosynthetic activities were observed weekly through a measure of chlorophyll $a$ fluorescence using Junior Pulse Amplitude Modulated (Junior-PAM) fluorometer (Walz, Germany). Dark-adapted photosystem II (PSII) photochemical efficiency was measured as maximum quantum yield (MQY) before lights were on $(n=4)$. Rapid Light Curves (RLCs) were determined $(n=4)$ with 9 increasing actinic light intensities $(0,66,90,125$, 190, 285, 420, 625 and $920 \mu \mathrm{mol}$ photons $\mathrm{m}^{-2} \mathrm{~s}^{-1}$ ), with $0.8 \mathrm{~s}$ saturating pulse (> $4500 \mu \mathrm{mol}$ photons $\mathrm{m}^{-2} \mathrm{~s}^{-1}$ ) between each actinic light intensity every $10 \mathrm{~s}$. Effective quantum yield (EQY), maximum relative electron transport rate $\left(\mathrm{rETR}_{\max }\right)$, minimum saturating irradiance $\left(\mathrm{I}_{\mathrm{k}}\right)$ and initial slope (Alpha $(\alpha)$ ) of each RLC were calculated using curve fitting protocols following Ralph and Gademann (2005).

\section{Chlorophyll $a$ and $b$ concentrations}

Photosynthetic pigment concentrations (chlorophyll (Chl) $a$ and $b$ ) were determined $(n=4)$ using the standard spectrophotometric method of Ritchie (2006). Chlorophyll $a$ and $b\left(\mu \mathrm{g} \mathrm{g}^{-1} \mathrm{fw}\right)$ were extracted by homogenizing samples in $4 \mathrm{ml}$ of $90 \%$ acetone at $4{ }^{\circ} \mathrm{C}$ for $24 \mathrm{~h}$. Samples were then centrifuged at $1500 \mathrm{~g}$ for $10 \mathrm{~min}$ and the supernatant was placed in a quartz cuvette for the spectrophotometer (Metertech, SP8001, 190-1100 nm), and absorbance was measured at 647, 664 and $750 \mathrm{~nm}$.

\section{Growth rate}

Growth rates of $C$. demersum and $E$. canadensis were determined $(n=4)$ as changes in total length per day, using equation (Eq.1) that is modified from Knauer et al. (2006).

$$
\text { Growth rate }=(\text { final length }- \text { initial length }) / \text { day }
$$

\section{Organic and carbon contents}

Macrophyte samples were oven dried at $105^{\circ} \mathrm{C}$ and ground to less than $1 \mathrm{~mm}$ particle sizes. A $1.0 \mathrm{~g}$ ground sample was ashed in a muffle furnace (FHX, DAIHAN, China) at $550^{\circ} \mathrm{C}$ for $8 \mathrm{~h}$ (Armecin and Gabon, 2008). Organic matter in the macrophytes was determined using data from the ashed samples $(n=4)$, and mineral matter (MM;Eq.2), organic matter (OM;Eq.3) and organic carbon (OC; Eq.4) contents were computed as follows:

$$
\begin{gathered}
\% \mathrm{MM}=\left(\frac{\mathrm{AW}}{\mathrm{DW}}\right) \times 100 \\
\% \mathrm{OM}=100 \times(\mathrm{DW}-\mathrm{AW}) / \mathrm{DW}
\end{gathered}
$$




$$
\% \mathrm{OC}=\% \mathrm{OM} / 1.724
$$

where AW and DW are ash weight and dry weight of the sample, respectively (Armecin and Gabon, 2008).

\section{Statistical analyses}

Three-way mixed ANOVA tests were used to test for significant differences among treatments over time, in the chlorophyll fluorescence parameters. Two-way ANOVA was used to test for significant differences among treatments and species in leaf pigments, growth rate, and organic content. All tests were performed with a significance level of $95 \%$, and Tukey's honestly significant difference post hoc tests were used to verify statistical significances. If the data did not meet the assumptions of normality (Kolmogorov-Smirnov test) and constant variance (Levene's test), they were transformed using square root or $\log _{10}$. If the transformed data did not meet the assumptions, then non-parametric tests were used.

\section{Results}

\section{Photosynthetic activity}

Responses of photosynthetic activity were measured under ambient temperature $\left(30^{\circ} \mathrm{C}\right)$, or elevated temperature $\left(33\right.$ and $\left.36^{\circ} \mathrm{C}\right)$ with ambient light $(180 \mu \mathrm{mol}$ photons $\mathrm{m}^{-2} \mathrm{~s}^{-1}$ ) or low light ( 90 and $45 \mu \mathrm{mol}$ photons $\left.\mathrm{m}^{-2} \mathrm{~s}^{-1}\right)$. Results showed differences in photosynthetic activity for each macrophyte species.

\section{Maximum quantum yield (MQY)}

At week 0, MQY of Ceratophyllum demersum and Elodea canadensis was $0.77 \pm 0.01$ and $0.76 \pm 0.03$, respectively. A difference between the species showed up at elevated temperature $\left(36^{\circ} \mathrm{C}\right)$ where the lowest MQY of $C$. demersum $(0.61)$ occurred in T36L180 (Fig. 3a). On the other hand, E. canadensis in T36L180 treatment significantly decreased at week $1(\mathrm{p}<0.05)$ then followed by T36L90 at week 3 and by T36L45 at week 4 (Fig. $3 b)$. At the end of experiment, there were significant differences in MQY among the treatments in both species $(\mathrm{p}<0.05)$. The data indicate that only temperature affected MQY of $C$. demersum (p<0.05) while MQY of E. canadensis was affected by both light and temperature $(\mathrm{p}<0.05)$.
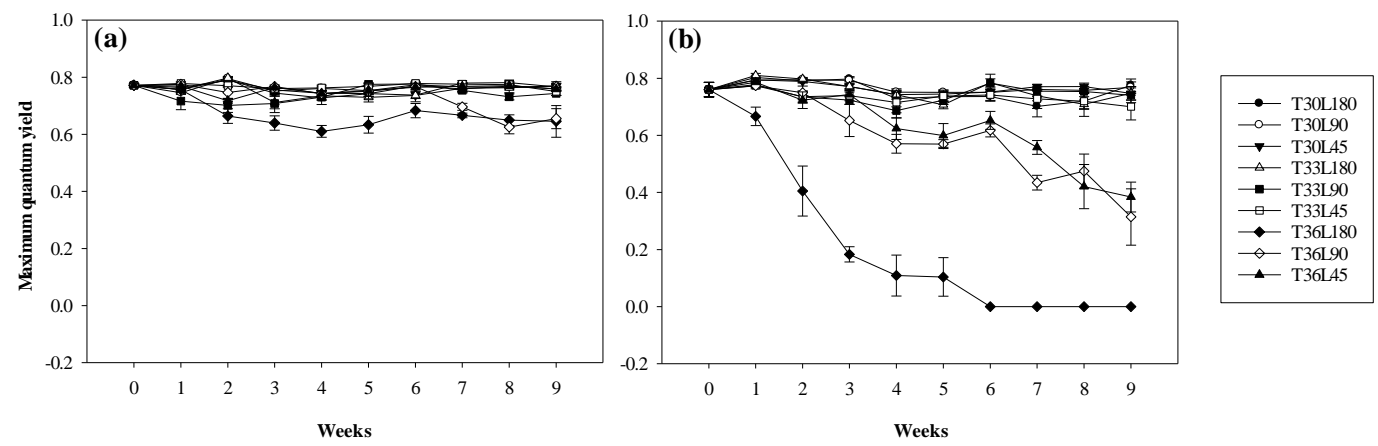

Figure 3. Maximum quantum yields of $C$. demersum (a), and E. canadensis (b) from Week 0 to Week 9 in each treatment. Data are shown as Mean $\pm S E$ 


\section{Effective quantum yield (EQY)}

At week 0, EQY of $C$. demersum and E. canadensis was $0.68 \pm 0.01$ and $0.73 \pm 0.01$, respectively. EQY showed similar trends to MQY for both species, and at the end of experiment there were significant differences in EQY among the treatments $(\mathrm{p}<0.05)$. T36L180 treatment gave the lowest of EQY in both species (Figs. $4 a$ and $b$ ) but it instantly decreased in E. canadensis. EQY of $C$. demersum and E. canadensis depended on both light and temperature $(\mathrm{p}<0.05)$ and there was significant difference between the species $(\mathrm{p}<0.05)$.
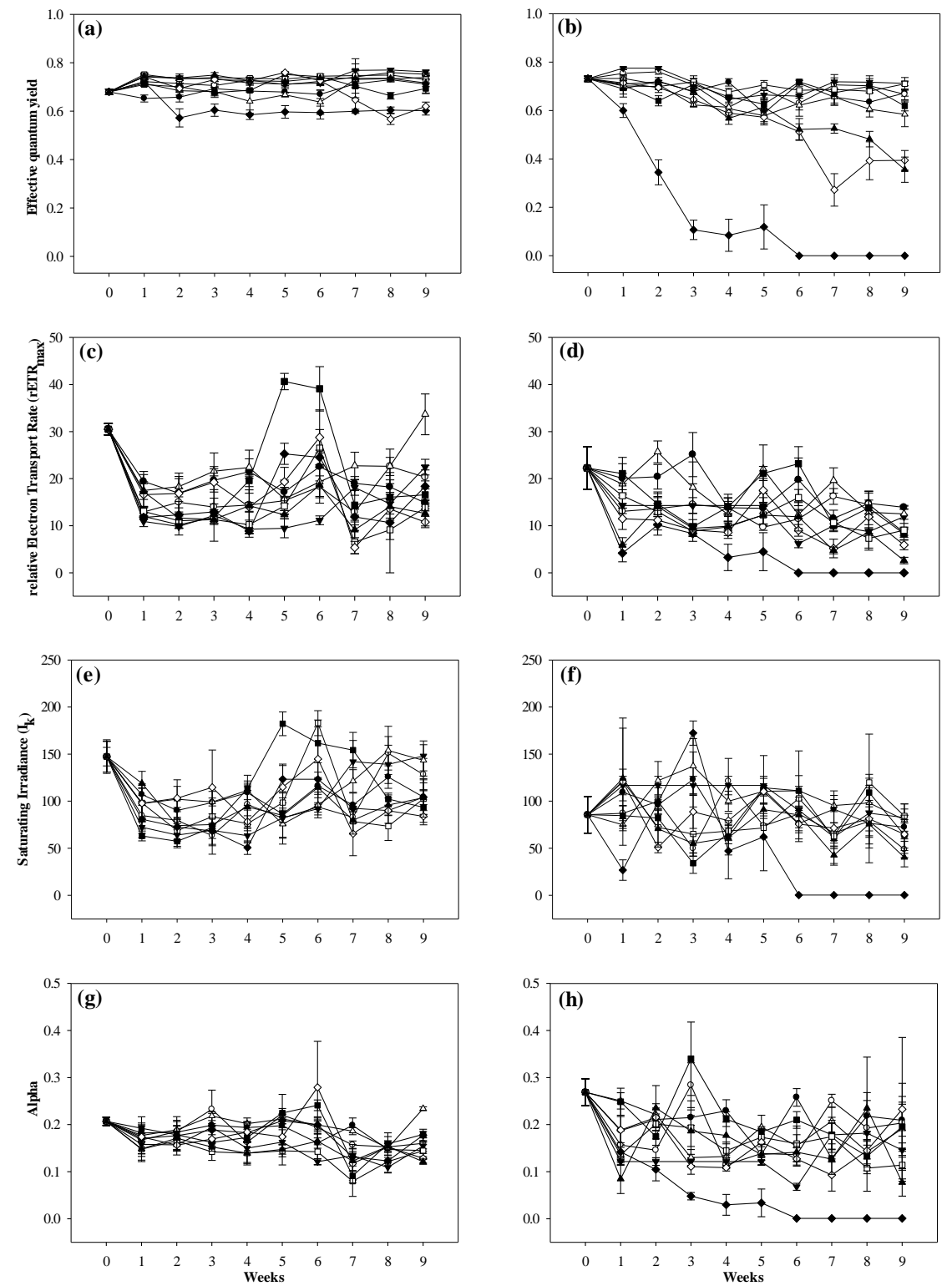

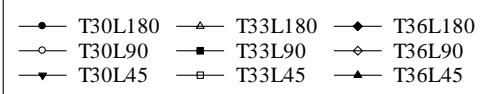

Figure 4. Effective Quantum Yield (EQY; a,b), maximum relative Electron Transport Rate $(r E T R m ; c, d)$, Saturating Irradiance $\left(I_{k} ; e, f\right)$ and Alpha $(\alpha ; g, h)$ from Week 0 to Week 9 for $C$. demersum $(a, c, d)$ and E. canadensis $(b, d, f)$ in each treatment. Data are shown as Mean $\pm S E$ 


\section{Maximum relative electron transport rate $\left(r E T R_{\max }\right)$}

At week $0, \mathrm{rETR}_{\max }$ of $C$. demersum and E. canadensis were $30.49 \pm 1.21$ and $22.25 \pm 4.54 \mu \mathrm{mol}$ electrons $\mathrm{m}^{-2} \mathrm{~s}^{-1}$, respectively. $\mathrm{rETR}_{\max }$ of $C$. demersum did not significantly change from week 1 to week 9 (13.56 to $18.82 \mu \mathrm{mol}$ electrons $\mathrm{m}^{-2} \mathrm{~s}^{-1}$; Fig. 4c) while high EETR $_{\max }$ was mostly found in T33L180 treatment. However, $\mathrm{rETR}_{\max }$ of $E$. canadensis slightly decreased from week 0 to week 9 and ranged between 8.07 to $15.22 \mu \mathrm{mol}$ electrons $\mathrm{m}^{-2} \mathrm{~s}^{-1}\left(\right.$ Fig. $4 d$ ), with high $\mathrm{rETR}_{\max }$ mostly found in T33L180 and T33L90 and low found in T36L180. At week 9, rETR max $_{\text {ax }}$ significantly differed by treatment in both species $(\mathrm{p}<0.05)$. $\mathrm{rETR}_{\max }$ of both species depended on light and temperature $(\mathrm{p}<0.05)$ and was significantly different by species $(\mathrm{p}<0.05)$.

\section{Saturating irradiance $\left(I_{k}\right)$}

At week $0, \mathrm{I}_{\mathrm{k}}$ of $C$. demersum and E. canadensis was $147.32 \pm 16.36$ and $85.57 \pm 19.50 \mu \mathrm{mol}$ photons $\mathrm{m}^{-2} \mathrm{~s}^{-1}$, respectively. $\mathrm{I}_{\mathrm{k}}$ in $C$. demersum significantly increased from week 2 to end of the experiment (Fig. 4e) continually. On the other hand, E. canadensis showed quite stable trend in the range from 59.70 to $96.18 \mu \mathrm{mol}$ photons $\mathrm{m}^{-2} \mathrm{~s}^{-1}$ (Fig. 4f). $\mathrm{I}_{\mathrm{k}}$ was not significantly different between treatments at the end of experiment for $C$. demersum ( $>0.05$ ) and there was no significant dependence on light or temperature ( $\mathrm{p}>0.05)$. In contrast, E. canadensis showed significant differences between treatments at the end of experiment $(\mathrm{p}<0.05)$ and also by temperature $(\mathrm{p}<0.05)$, and there were significant differences by species $(\mathrm{p}<0.05)$. $\mathrm{I}_{\mathrm{k}}$ for each treatment and species significantly differed by week $(\mathrm{p}<0.05)$. $\mathrm{I}_{\mathrm{k}}$ of $C$. demersum showed acclimation in the last two weeks in 33 and $36^{\circ} \mathrm{C}$ treatments, while E. canadensis showed acclimation in the last four weeks to 45 and $90 \mu \mathrm{mol}$ photons $\mathrm{m}^{-2} \mathrm{~s}^{-1}$ treatments.

\section{$\operatorname{Alpha}(\alpha)$}

At week $0, \alpha$ of $C$. demersum and E. canadensis was $0.21 \pm 0.01$ and $0.27 \pm 0.03$, respectively (Figs. $4 \mathrm{~g}$ and $4 \mathrm{~h}$ ). At the end of experiment, there were significant differences in $\alpha$ by treatment for $C$. demersum $(\mathrm{p}<0.05)$ but not for $E$. canadensis. High $\alpha$ was mostly found in 180 and $90 \mu \mathrm{mol}$ photons $\mathrm{m}^{-2} \mathrm{~s}^{-1}$ treatments for $C$. demersum, while E. canadensis showed various trends. It was found that only light affected $\alpha$ of $C$. demersum but $E$. canadensis was significantly affected by both light and temperature $(\mathrm{p}<0.05)$ and the difference between species was not significant $(\mathrm{p}>0.05)$.

\section{Chlorophyll $a$ and $b$ concentrations}

\section{Chlorophyll a (Chl a)}

Chl $a$ concentration of $C$. demersum and $E$. canadensis at week 0 was $1,953.27 \pm 301.05$ and $2,131.66 \pm 324.50 \mu \mathrm{g} \mathrm{g}^{-1} \mathrm{fw}$, respectively. Decreasing Chl $a$ concentration with time was observed in both species and in all treatments (Figs. 5a and 5b). At week 8, Chl $a$ concentration of both species was significantly different by treatment $(p<0.05)$ and highest in T30L180 and T33L90 for C. demersum and E. canadensis. T30L180 gave the highest $\mathrm{Chl} a$ concentration for $C$. demersum while the lowest was observed with T33L180, T33L90 and T33L45 treatments of E. canadensis. It was found that Chl $a$ significantly depended on temperature $(\mathrm{p}<0.05)$ and $\mathrm{Chl} a$ of $C$. demersum at $30^{\circ} \mathrm{C}$ was higher than at other tested temperatures, while $\mathrm{Chl} a$ of E. canadensis in $36^{\circ} \mathrm{C}$ treatment was lower than at other temperatures. 


$$
-2583-
$$
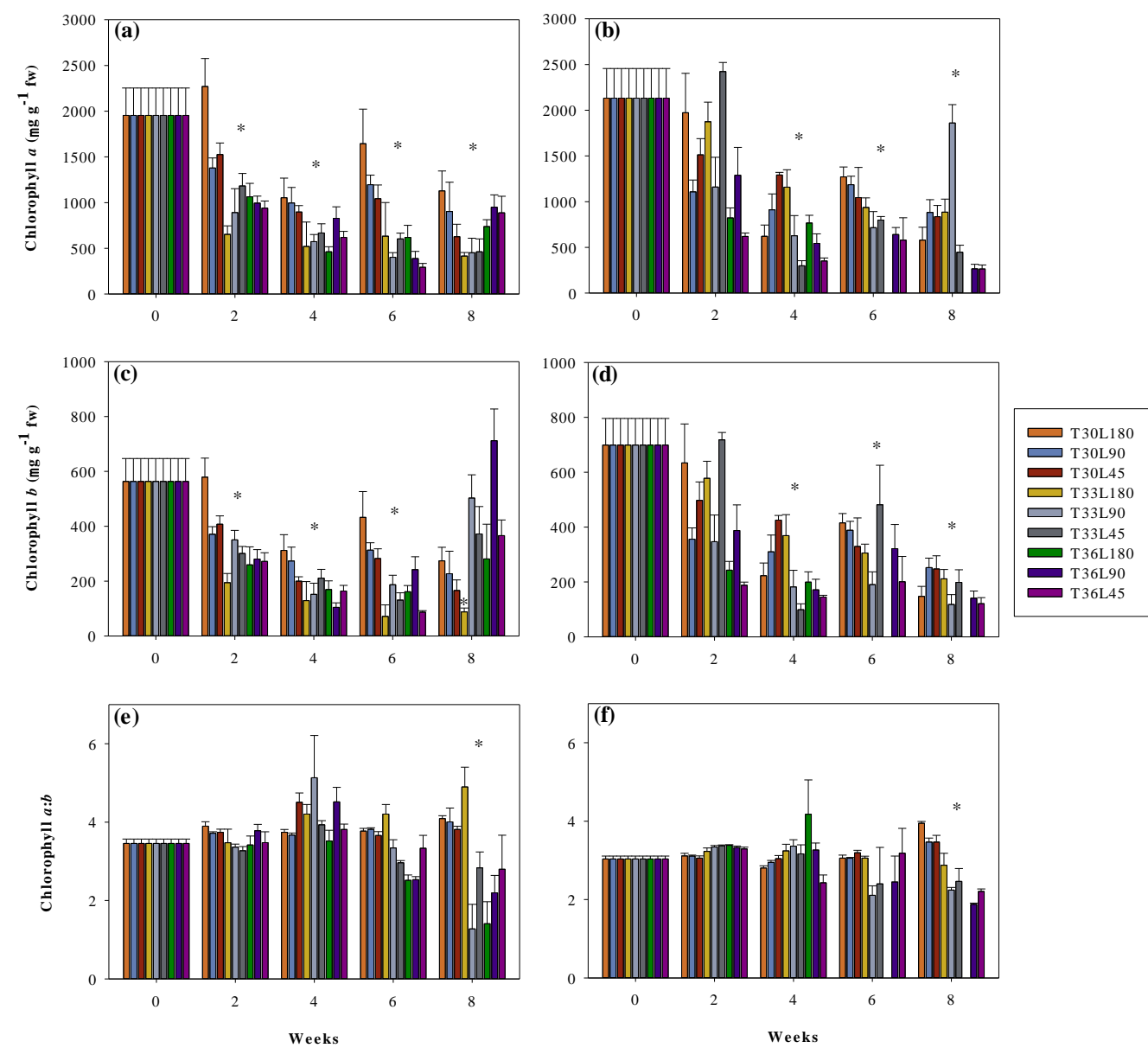

Figure 5. Chlorophyll $a(a, b)$ and $b(c, d)$ concentrations and chlorophyll a:b ratio $(e, f)$ at Week $O$ and Week 9 for C. demersum (left) and E. canadensis (right) in each treatment. Data are shown as Mean $\pm S E$ and * represent significant difference

\section{Chlorophyll b (Chl b)}

Chl $b$ concentration of $C$. demersum and $E$. canadensis at week 0 was $563.88 \pm 83.47$ and $699.50 \pm 96.80 \mu \mathrm{g} \mathrm{g}^{-1} \mathrm{fw}$, respectively. Chl $b$ of $C$. demersum decreased from week 2 to week 6 , then increased at week 8 with an elevated temperature treatment (T33 or T36). Chl $b$ of E. canadensis tended to dramatically decrease until the end of experiment (Figs. 5c and 5d). At week 8, Chl $b$ was significantly different between the treatments $(\mathrm{p}<0.05)$ in both species being highest in T36L90 for $C$. demersum and in T33L90 for E. canadensis. Chl $b$ of $C$. demersum did not significantly depend on temperature or light (p>0.05) but for $E$. canadensis it significantly depended on temperature $(\mathrm{p}<0.05)$ and was significantly different between the species $(\mathrm{p}<0.05)$.

\section{Chlorophyll a:b ratio}

Chl $a: b$ ratio of $C$. demersum and E. canadensis at week 0 was $3.46 \pm 0.11$ and $3.04 \pm 0.07$, respectively. Response mostly showed in week 4 and was higher for C. demersum $30^{\circ} \mathrm{C}$ treatments showed more stable trends of Chl $a: b$ ratio than the 33 and $36^{\circ} \mathrm{C}$ treatments that gave slight decreases over time (Figs. $5 e$ and $5 f$ ). There was a 
significant difference between the species and both species' responses significantly depended on temperature $(\mathrm{p}<0.05)$. At week 8 , there were significant differences by treatment in both species $(\mathrm{p}<0.05)$.

\section{Growth rates}

Growth of $C$. demersum and $E$. canadensis was measured from week 0 to week 8 . The highest growth rate of $C$. demersum and E. canadensis was in T30L180 treatment, namely $0.45 \pm 0.06$ and $1.67 \pm 0.18 \mathrm{~cm} \mathrm{day}^{-1}$, respectively ( $\mathrm{p}<0.05$ ) (Figs. $6 a$ and $6 b$ ); and the lowest was in T36L180 treatment at $-0.04 \pm 0.01$ and $-0.05 \pm 0.00 \mathrm{~cm} \mathrm{day}^{-1}$, respectively $(\mathrm{p}<0.05)$. E. canadensis had significant faster growth than $C$. demersum in all treatments $(\mathrm{p}<0.05)$. Both species' growth significantly depended on temperature and light $(\mathrm{p}<0.05)$.
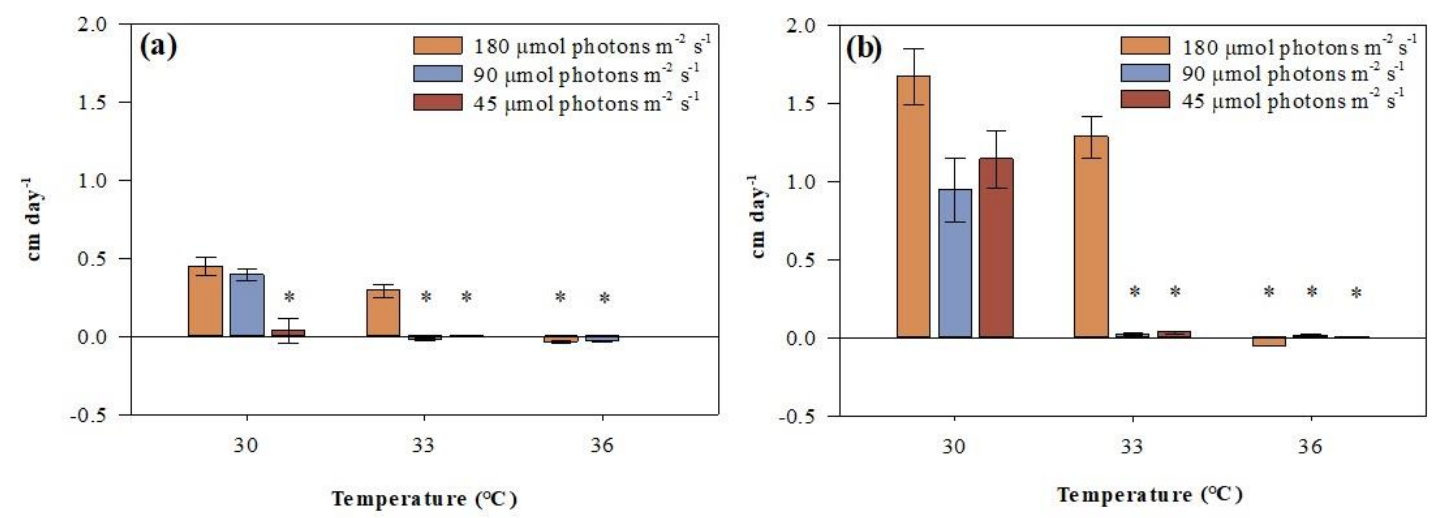

Figure 6. Growth rate $\left(\mathrm{cm} \mathrm{day}^{-1}\right)$ from Week 0 to Week 9 for C. demersum (a) and E. canadensis (b) in each treatment. Data are shown as Mean $\pm S E$ and $*$ represent significant difference

\section{Organic matter $(O M)$ and organic carbon $(O C)$ contents}

OM of $C$. demersum and E. canadensis at week 0 was $89.58 \pm 1.24 \%$ and $89.94 \pm 0.92 \%$, respectively. OM of $C$. demersum significantly decreased in week 8 in all treatments except for T33L180, but E. canadensis showed dramatic decrease from week 0 to week 8 (Figs. $7 a$ and $7 b$ ). There was a significant difference between treatments, with OM of $C$. demersum the lowest in T36L90 and the highest in T30L180, while OM of E. canadensis was the lowest in T36L180 and the highest in T36L45 treatment. However, there was no significant difference between the species, but at week 8 the OM of both species significantly differed by treatment $(p<0.05)$. Light and temperature did not significantly affect $\mathrm{OM}$ of $C$. demersum $(\mathrm{p}>0.05)$ but significantly affected $\mathrm{OM}$ of E. canadensis $(\mathrm{p}<0.05)$.

OC of $C$. demersum and E. canadensis at week 0 was $51.96 \pm 0.72 \%$ and $52.17 \pm 0.53 \%$, respectively. OC of both species showed similar trends to OM (Figs. $7 c$ and $7 d$ ) and there were significant differences by treatment. OC of $C$. demersum was the lowest in T36L90 and the highest in T30L180, while OC of E. canadensis was the lowest in T36L180 and the highest in T36L45 treatment. OC of both species significantly differed by treatment $(\mathrm{p}<0.05)$ at the end of experiment. Light and temperature did not significantly affect OC of $C$. demersum ( $>>0.05$ ) but both significantly affected OC of E. canadensis ( $<<0.05)$. 

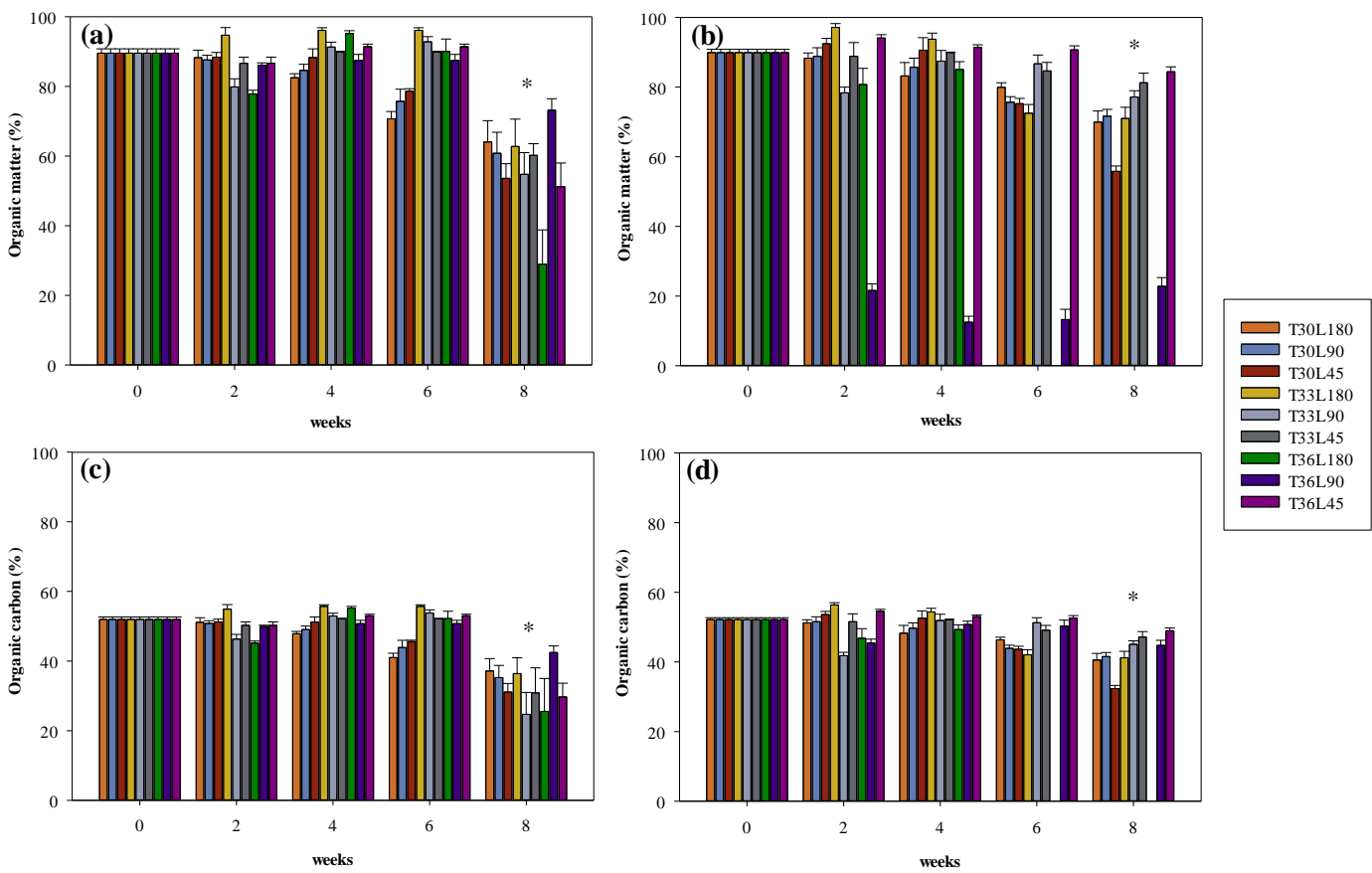

Figure 7. Organic matter $(a, b)$ and organic carbon contents $(c, d)$ at Week 0 to Week 8 for $C$. demersum $(a, c)$ and E. canadensis $(b, d)$ in each treatment. Data are shown as Mean $\pm S E$ and * represent significant difference

\section{Discussion}

The combined effects of elevated temperature and low light were investigated in $C$. demersum and E. Canadensis, which are the dominant species in the middle of Songkhla lagoon, for 9 weeks. Photosynthetic performance of both species was affected by temperature and/or low light, as seen in the maximum quantum yield (MQY). Elevated temperature and ambient light $\left(36^{\circ} \mathrm{C}\right.$ and $180 \mu \mathrm{mol}$ photons $\left.\mathrm{m}^{-2} \mathrm{~s}^{-1}\right)$ showed faster down-regulation of $C$. demersum photosynthesis at week 2 , while elevated temperature with $50 \%$ shading $\left(36^{\circ} \mathrm{C}\right.$ and $90 \mu \mathrm{mol}$ photons $\mathrm{m}^{-2} \mathrm{~s}^{-1}$ treatment $)$ caused down-regulation at weeks 2 and 7 . On the other hand, other light shading at a lower temperature (30 or $33^{\circ} \mathrm{C}$ ) did not induce changes in MQY. This indicates that the temperature had stronger effects on photosynthesis performance of $C$. demersum than light shading. This result is consistent with Jiang et al. (2018) who found no difference in MQY of $C$. demersum between shade and no shade. On the other hand, E. canadensis was more sensitive to temperature and light stress, showing response to $36^{\circ} \mathrm{C}$ treatment at weeks 1,3 and 4 with 180,90 , and $45 \mu \mathrm{mol}$ photons $\mathrm{m}^{-2} \mathrm{~s}^{-1}$, respectively. This is consistent with Chalanika De Silva and Asaeda (2017) reporting that the PSII activity of E. nuttallii was significantly reduced under elevated temperatures. The present study showed that a combination of ambient light and elevated temperature induced the greatest impact in photosynthetic activities of both tested species, especially E. canadensis. Netten et al. (2013) showed that the effects of elevated temperature and low light on E. canadensis are most likely caused by increased metabolic activity and reduced photosynthesis, to respectively adjust photo-physiology and to maintain a net positive carbon balance (Chartrand et al., 2018).

Climate change scenario and human activities could change many environment factors (Gallardo et al., 2017) especially light and temperature, which are among the main factors 
for growth of aquatic plants (Carr et al., 1997). Thus, to maintain positive carbon balance and cope with light and temperature conditions, macrophytes had strategies, such as adjustments of light harvesting capacity and light use efficiency and modifying rates of growth (Chartrand et al., 2018). Moreover, light harvesting capacity (threshold) of each species can specify the species composition in the future, which faces climate and anthropogenic changes.

Light threshold for photosynthesis was shown by saturating irradiance $\left(\mathrm{I}_{\mathrm{k}}\right)$. Our results indicate that E. canadensis was not affected by low light (high turbidity of water) and there was faster adaptation ( $\mathrm{I}_{\mathrm{k}}$ close to the light intensity) in the last 4 weeks in 90 and $45 \mu \mathrm{mol}$ photons $\mathrm{m}^{-2} \mathrm{~s}^{-1}$ treatments, while $C$. demersum showed response in the last two weeks. C. demersum was more tolerant to ambient light $\left(180 \mu \mathrm{mol}\right.$ photons $\left.\mathrm{m}^{-2} \mathrm{~s}^{-1}\right)$, consistent with Jiang et al. (2018) stating that different light regimes did not show different photosynthetic activities in $C$. demersum; while the growth rate of $C$. demersum was lower in the light limited treatments than the rate of E. canadensis that was not affected.

E. canadensis was more sensitive to elevated temperature than $C$. demersum as shown by all indicators measured. $C$. demersum had more tolerance of a wide range of temperatures, and temperature did not much affect photosynthetic activities as C. demersum achieved homeostasis in photosynthesis and respiration rates, and the temperature optimum for photosynthesis changed according to its acclimation temperature (Hyldgaard et al., 2014). Elevated temperature, in contrast, did affect photosynthetic activities, chlorophyll concentration and carbon contents of E. canadensis.

Changes of environment by changing light intensity and temperature affect species composition ( $\mathrm{Li}$ et al., 2017). Macrophytes capable of adaptation will survive and dominate in the lagoon. Decreasing light in a water column induced changes in photosynthetic activities, shown in the $\alpha$ for both tested species. Changes of $\alpha$ revealed the light responses clearly in $C$. demersum. Although $C$. demersum was able to adapt to a low light, due to the lower energy available the low light regime slowed down growth of $C$. demersum. E. canadensis showed various response in $\alpha$, induced by combinations of light and temperature.

Only T33L90 treatment had increasing Chl $a$ and $b$, revealing that only optimal temperature and light intensity allowed E. canadensis to thrive. Similar results were shown in E. nuttallii which Chl $a$ and $\mathrm{Chl} b$ significantly increasing in a $30^{\circ} \mathrm{C}$ heat shock treatment and decreasing in a $35^{\circ} \mathrm{C}$ heat shock treatment (Chalanika De Silva and Asaeda, 2017). C. demersum showed increasing Chl $a$ and $b$ in T33L45, T36L90 and T36L45 to maintain photosynthetic activities. This reveals a wider range of temperature and light to which $C$. demersum can adapt, by more light harvesting in a low light regime, consistent with Dar et al. (2013) that found that the pigment in $C$. demersum was positively correlated with water temperature.

Macrophytes are fast growing plants that can on their death make a large amount of carbon settle to the bottom. Climate change and anthropogenic changes will affect growth (Zhang et al., 2018), species compositions (Li et al., 2017) and the carbon sink function as well. Carbon content of these 2 species did not differ, but only E. canadensis showed response to low light and elevated temperature that affected its photosynthetic activities. Degraded photosynthesis affected carbon capture by the macrophyte and reduced organic matter and organic carbon. Thus, reducing a macrophyte's carbon capture might reduce carbon sink efficiency in a lagoon, and might affect other species around the macrophyte. 
Mal et al. (2002) found that E. canadensis growth (in control) was about $1.4 \mathrm{~cm}$ per day. Comparing $C$. demersum and $E$. canadensis for growth in similar conditions, Pinowska (2002) found that E. canadensis (final weight increased by about $17 \%$ of initial fresh weight) grew faster than $C$. demersum (final weight increased by about $7 \%$ of initial fresh weight) which is consistent with this current study.

Growth rates showed that $30^{\circ} \mathrm{C}$ was a near optimal temperature for growth of both species. At this temperature, E. canadensis had 2-3 times higher growth rates than C. demersum because the habitats of these species differ in position in the water column. C. demersum is a free-floating aquatic plant (Huxley et al., 1992) mostly found at the water surface where it can get full force of the sunlight, while E. canadensis is a submergent macrophyte with roots growing in the muddy bottom (Huxley et al., 1992) where it could be shaded by other plants and/or sediments. Thus, fast expansion is a strategy to get more sunlight. Previous research on competition of E. nuttallii with Myriophyllum verticillatum, Vallisneria natans and $C$. demersum found that E. nuttallii grew the fastest and its expansion ability was the strongest in autumn-winter and spring, but degenerated in the summer (Duan et al., 2011). In terms of species composition, there are spatial and temporal dynamics in species composition among these 2 species, dependent on environmental factors. However, climate change and anthropogenic activities that change the environment will affect species compositions in the future.

Anthropogenic activities that induce eutrophication (Nwankwegu et al., 2019) and algal blooms or high turbidity, and decrease light penetration in a water column, might affect growth of $C$. demersum. The IPCC Representative Concentration Pathways (RCPs) 4.5 and 8.5 scenarios predict that average temperatures would increase by about 1 to $3^{\circ} \mathrm{C}$ in 2020-2050 (Science Framework Climate Working Group, 2016) and this might affect photosynthesis and carbon content of E. Canadensis, which can grow in narrow light intensity and temperature ranges.

Low light and elevated temperature will change species composition so that the scale of $E$. canadensis will decrease at an elevated temperature, while $C$. demersum might not decrease in scale but in growth. However, since $C$. demersum is a free-floating macrophyte on water surface, eutrophication might affect the light harvesting by $C$. demersum very little. Thus, in species composition $C$. demersum might increase and dominate in the lagoon. Due to different points in the water column for these 2 macrophytes species, the loss of $E$. canadensis might affect middle - bottom water column microhabitat and related ecosystem.

C. demersum can improve water quality, specifically turbidity and nutrients, but its overgrowth will have disadvantages, such as increased sediment accumulation, reduced light penetration, and dissolved oxygen. Dai et al. (2012) found that water quality measures, such as turbidity, chlorophyll $a$, and nutrient concentrations, improved significantly in the presence of $C$. demersum, but there was a negative correlation between these reductions and the coverage of $C$. demersum. Therefore, $20 \%$ is probably the optimal restoration coverage area for $C$. demersum in the lagoon.

These results indicate that $C$. demersum prefers ambient light intensity (180 and $90 \mu \mathrm{mol}$ photons $\mathrm{m}^{-2} \mathrm{~s}^{-1}$ ) while E. canadensis prefers ambient light with a comparatively low $\left(30^{\circ} \mathrm{C}\right)$ temperature. This study provided data related to species composition in a lagoon, associated to scenarios of climate change and expected anthropogenic activities in the future. 


\section{Conclusions}

To understand responses of macrophytes to climate change (RCP4.5 and RCP8.5) and to anthropogenic stresses, in terms of photosynthesis and carbon content, two dominant species from the middle of Songkhla lagoon in Thailand were subjected to experimental treatments in the lagoon. We found that photosynthetic activity indicators EQY, $\alpha$ and rETR $_{\max }$ in both species were induced by light. Then, pigmentation in both species depended also on temperature, while the carbon content of $C$. demersum was unaffected by temperature or light, and E. canadensis was affected by both. C. demersum was more tolerant to temperature and light stresses but had slower growth of the two species. As regards species composition, the limiting factor for $C$. demersum vegetation is light shading, while for E. canadensis elevated temperature may be limiting. This study should study more about biochemical and physiological stress responses such as protein content, catalase activity, lipid peroxidation, and cellular membrane permeability as well as in situ measurement to confirm the results of this study.

Acknowledgements. This work was supported by the Development and Promotion of Science and Technology Grant for New Scholar, The Institute for the Promotion of Teaching Science and Technology [Grant number: 026/2559]. Authors would like to thank Associate Professor Seppo Karrila and the Research and Development Office, PSU, for proofreading the English language.

\section{REFERENCES}

[1] Armecin, R. B., Gabon, F. M. (2008): Biomass, organic carbon and mineral matter contents of abaca (Musa textilis Nee) at different stages of growth. - Industrial Crops and Products 28(3): 340-345. https://doi.org/10.1016/j.indcrop.2008.03.014.

[2] Atta-Boateng, A., Berlyn, G. P., O'Hern, C. S., Felson, A. J. (2019): Suitability of wetland macrophyte in green cooling tower performance. - Ecological Engineering 127: 487-493. https://doi.org/10.1016/j.ecoleng.2018.08.002.

[3] Barko, J. W., Smart, R. M. (1981): Comparative influences of light and temperature on the growth and metabolism of selected submersed freshwater macrophytes. - Ecological Monographs 51: 219-235.

[4] Barko, J. W., Smart, R. M. (1983): Effects of organic matter additions to sediment on the growth of aquatic plants. - Journal of Ecology 71: 161-175.

[5] Barko, J. W., Hardin, D. G., Matthews, M. S. (1984): Interactive influences of light and temperature on the growth and morphology of submerged freshwater macrophytes. Technical Report A-84-3. U.S. Army Corps of Engineers, Waterways Experimental Station, Vicksburg.

[6] Cao, J., Ruan, H. (2015): Responses of the submerged macrophyte Vallisneria natans to elevated $\mathrm{CO}_{2}$ and temperature. - Aquatic Biology 23(2): 119-127. https://doi.org/10.3354/ab00605.

[7] Carr, G. M., Duthie, H. C., Taylor, W. D. (1997): Models of aquatic plant productivity: A review of the factors that influence growth. - Aquatic Botany 59(3-4): 195-215. https://doi.org/10.1016/S0304-3770(97)00071-5.

[8] Chalanika De Silva, H. C., Asaeda, T. (2017): Effects of heat stress on growth, photosynthetic pigments, oxidative damage and competitive capacity of three submerged macrophytes. - Journal of Plant Interactions 12(1): 228-236. https://doi.org/10.1080/17429145.2017.1322153.

[9] Chalanika De Silva, H. C., Asaeda, T. (2018): Stress response and tolerance of the submerged macrophyte Elodea nuttallii (Planch) St. John to heat stress: A comparative 
study of shock heat stress and gradual heat stress. - Plant Biosystems - An International Journal Dealing with All Aspects of Plant Biology 152(4): 787-794.

https://doi.org/10.1080/11263504.2017.1338628.

[10] Chartrand, K. M., Szabó, M., Sinutok, S., Rasheed, M. A., Ralph, P. J. (2018): Living at the margins - The response of deep-water seagrasses to light and temperature renders them susceptible to acute impacts. - Marine Environmental Research 136: 126-138. https://doi.org/10.1016/j.marenvres.2018.02.006.

[11] Chen, J., Cao, T., Zhang, X., Xi, Y., Ni, L., Jeppesen, E. (2016): Differential photosynthetic and morphological adaptations to low light affect depth distribution of two submersed macrophytes in lakes. - Scientific Reports 6(1). https://doi.org/10.1038/srep34028.

[12] Community Development Department, Ministry of Interior. (2009): Local basic population data report. - Community Development Department, Ministry of Interior.

[13] Cronk, J. K., Fennessy, M. S. (2016): Wetland plants: biology and ecology. - CRC press.

[14] Dai, Y., Jia, C., Liang, W., Hu, S., Wu, Z. (2012): Effects of the submerged macrophyte Ceratophyllum demersum L. on restoration of a eutrophic waterbody and its optimal coverage. - Ecological Engineering 40: 113-116. https://doi.org/10.1016/j.ecoleng.2011.12.023.

[15] Dar, N., Pandit, A., Ganai, B. (2013): Seasonal Variation in the Pigment Content of Dominant Macrophytes from Wular lake, Kashmir Himalaya, India. - Biochemistry \& Pharmacology: Open Access 02(04). https://doi.org/10.4172/2167-0501.1000124.

[16] Duan, D., Yu, J., Yang, J., Hu, Q., Ma, S., Ren, S., Ma, J., Ren, S., Ma, J. (2011): Research on competition of Elodea nuttallii with Myriophyllum verticillatum, Vallisneria natans and Ceratophyllum demersum. - Journal of Henan Agricultural Sciences 40(8): 149-155.

[17] Eissa, A. E., Zaki, M. M. (2011): The impact of global climatic changes on the aquatic environment. - Procedia Environmental Sciences 4: 251-259. https://doi.org/10.1016/j.proenv.2011.03.030.

[18] Eller, F., Alnoee, A. B., Boderskov, T., Guo, W.-Y., Kamp, A. T., Sorrell, B. K., Brix, H. (2015): Invasive submerged freshwater macrophytes are more plastic in their response to light intensity than to the availability of free $\mathrm{CO}_{2}$ in air-equilibrated water. - Freshwater Biology 60(5): 929-943. https://doi.org/10.1111/fwb.12547.

[19] Fernández, P. A., Gaitán-Espitia, J. D., Leal, P. P., Schmid, M., Revill, A. T., Hurd, C. L. (2020): Nitrogen sufficiency enhances thermal tolerance in habitat-forming kelp: Implications for acclimation under thermal stress. - Scientific Reports 10(1). https://doi.org/10.1038/s41598-020-60104-4.

[20] Gallardo, B., Aldridge, D. C., González-Moreno, P., Pergl, J., Pizarro, M., Pyšek, P., Thuiller, W., Yesson, C., Vilà, M. (2017): Protected areas offer refuge from invasive species spreading under climate change. - Global Change Biology 23(12): 5331-5343. https://doi.org/10.1111/gcb.13798.

[21] Gonzalez, P. (2010): Impacts of Climate Change on Terrestrial Ecosystems and Adaptation Measures for Natural Resource Management. - In: Dodson, J. (ed.) Changing Climates, Earth Systems and Society. Springer, Netherlands. https://doi.org/10.1007/978-90-4818716-4_2.

[22] Hanelt, D. (1992): Photoinhibition of photosynthesis in marine macrophytes of the South China Sea. - Marine ecology progress series 82(2): 199-206.

[23] Howarth, R. W., Swaney, D. P., Butler, T. J., Marino, R. (2000): Rapid Communication: Climatic Control on Eutrophication of the Hudson River Estuary. - Ecosystems 3(2): 210215. https://doi.org/10.1007/s100210000020.

[24] Huxley, A. J., Griffiths, M., Royal Horticultural Society (Great Britain) (eds.). (1992): Dictionary of gardening. - Macmillan Press, Stockton Press.

[25] Hyldgaard, B., Sorrell, B., Brix, H. (2014): Closely related freshwater macrophyte species, Ceratophyllum demersum and C. submersum, differ in temperature response. - Freshwater Biology 59(4): 777-788. https://doi.org/10.1111/fwb.12303. 
[26] Intergovernmental Panel on Climate Change. (2013): Climate change 2013: synthesis report. Contribution of working groups I, II and III to the fourth assessment report of the intergovernmental panel on climate change. - Intergovernmental Panel on Climate Change, Geneva.

[27] Jiang, H. S., Zhang, Y., Yin, L., Li, W., Jin, Q., Fu, W., Zhang, T., Huang, W. (2018): Diurnal changes in photosynthesis by six submerged macrophytes measured using fluorescence. - Aquatic Botany 149: 33-39. https://doi.org/10.1016/j.aquabot.2018.05.003.

[28] Jin, S., Ibrahim, M., Muhammad, S., Khan, S., Li, G. (2020): Light intensity effects on the growth and biomass production of submerged macrophytes in different water strata. Arabian Journal of Geosciences 13(18): 948. https://doi.org/10.1007/s12517-020-05924-4.

[29] Johnson, J. E., Marshall, P. A., Great Barrier Reef Marine Park Authority (2007): Climate change and the Great Barrier Reef: a vulnerability assessment. - Great Barrier Reef Marine Park Authority and the Australian Greenhouse Office.

[30] Knauer, K., Vervliet-Scheebaum, M., Dark, R. J., Maund, S. J. (2006): Methods for assessing the toxicity of herbicides to submersed aquatic plants. - Pest Management Science 62(8): 715-722. https://doi.org/10.1002/ps.1226.

[31] Korschgen, C. E., Green, W. L., Kenow, K. P. (1997): Effects of irradiance on growth and winter bud production by Vallisneria americana and consequences to its abundance and distribution. - Aquatic Botany 58(1): 1-9. https://doi.org/10.1016/S0304-3770(97)000144.

[32] Kovtun-Kante, A., Torn, K., Kotta, J. (2014): In situ production of charophyte communities under reduced light conditions in a brackish-water ecosystem. - Estonian Journal of Ecology 63(1): 28. https://doi.org/10.3176/eco.2014.1.03.

[33] Li, Z., He, L., Zhang, H., Urrutia-Cordero, P., Ekvall, M. K., Hollander, J., Hansson, L.-A. (2017): Climate warming and heat waves affect reproductive strategies and interactions between submerged macrophytes. - Global Change Biology 23(1): 108-116. https://doi.org/10.1111/gcb.13405.

[34] Li, W., Li, Y., Zhong, J., Fu, H., Tu, J., Fan, H. (2018): Submerged Macrophytes Exhibit Different Phosphorus Stoichiometric Homeostasis. - Frontiers in Plant Science 9. https://doi.org/10.3389/fpls.2018.01207.

[35] Liu, G. F., Zhang, L., Fan, C. X., Han, S. Q., He, J., Paerl, H. W. (2000): The Response of Macrophytes to Nutrients and Implications for the Control of Phytoplankton Blooms in East Taihu Lake, China. - Journal of Pollution Effects \& Control: 1-5.

[36] Lone, P. A., Bhardwaj, A. K., Shah, K. W. (2014): Macrophytes as powerful natural tools for water quality improvement. - Research Journal of Botany 9(2): 24.

[37] Mal, T. K., Adorjan, P., Corbett, A. L. (2002): Effect of copper on growth of an aquatic macrophyte, Elodea canadensis. - Environmental Pollution 120(2): 307-311. https://doi.org/10.1016/S0269-7491(02)00146-X.

[38] Mi, H., Fagherazzi, S., Qiao, G., Hong, Y., Fichot, C. G. (2019): Climate change leads to a doubling of turbidity in a rapidly expanding Tibetan lake. - Science of The Total Environment 688: 952-959. https://doi.org/10.1016/j.scitotenv.2019.06.339.

[39] Miller, A. D., Coleman, M. A., Clark, J., Cook, R., Naga, Z., Doblin, M. A., Hoffmann, A. A., Sherman, C. D. H., Bellgrove, A. (2020): Local thermal adaptation and limited gene flow constrain future climate responses of a marine ecosystem engineer. - Evolutionary Applications 13(5): 918-934. https://doi.org/10.1111/eva.12909.

[40] Netten, J. J. C., van der Heide, T., Smolders, A. J. P. (2013): Interactive effects of pH, temperature and light during ammonia toxicity events in Elodea canadensis. - Chemistry and Ecology 29(5): 448-458. https://doi.org/10.1080/02757540.2013.769971.

[41] Nwankwegu, A. S., Li, Y., Huang, Y., Wei, J., Norgbey, E., Sarpong, L., Lai, Q., Wang, K. (2019): Harmful algal blooms under changing climate and constantly increasing anthropogenic actions: The review of management implications. - 3 Biotech 9(12): 449. https://doi.org/10.1007/s13205-019-1976-1. 
[42] Pinowska, A. (2002): Effects of snail grazing and nutrient release on growth of the macrophytes Ceratophyllum demersum and Elodea canadensis and the filamentous green alga Cladophora sp. - Hydrobiologia 479(1/3): 83-94.

https://doi.org/10.1023/A:1021070616130.

[43] Pongpiachan, S., Tipmanee, D., Choochuay, C., Hattayanone, M., Deelaman, W., Iadtem, N., Bunsomboonsakul, S., Palakun, J., Poshyachinda, S., Leckngam, A., Somboonpon, P., Panyaphirawat, T., Aukkaravittayapun, S., Wang, Q., Xing, L., Li, G., Han, Y., Cao, J. (2019): Vertical profile of organic and elemental carbon in sediments of Songkhla Lake, Thailand. - Limnology 20(2): 203-214. https://doi.org/10.1007/s10201-018-0568-9.

[44] Pradit, S., Wattayakorn, G., Angsupanich, S., Baeyens, W., Leermakers, M. (2010): Distribution of Trace Elements in Sediments and Biota of Songkhla Lake, Southern Thailand. - Water, Air, and Soil Pollution 206(1-4): 155-174. https://doi.org/10.1007/s11270-009-0093-x.

[45] Qiu, D., Wu, Z., Liu, B., Deng, J., Fu, G., He, F. (2001): The restoration of aquatic macrophytes for improving water quality in a hypertrophic shallow lake in Hubei Province, China. - Ecological Engineering 18(2): 147-156. https://doi.org/10.1016/S0925-8574(01)00074-X.

[46] Ralph, P. J., Gademann, R. (2005): Rapid light curves: A powerful tool to assess photosynthetic activity. - Aquatic Botany 82(3): 222-237. https://doi.org/10.1016/j.aquabot.2005.02.006.

[47] Raun, A. L., Borum, J., Sand-Jensen, K. (2010): Influence of sediment organic enrichment and water alkalinity on growth of aquatic isoetid and elodeid plants: Organic matter and alkalinity influence plant growth. - Freshwater Biology 55(9): 1891-1904. https://doi.org/10.1111/j.1365-2427.2010.02423.x.

[48] Reitsema, R. E., Meire, P., Schoelynck, J. (2018): The Future of Freshwater Macrophytes in a Changing World: Dissolved Organic Carbon Quantity and Quality and Its Interactions with Macrophytes. - Frontiers in Plant Science 9. https://doi.org/10.3389/fpls.2018.00629.

[49] Ritchie, R. J. (2006): Consistent Sets of Spectrophotometric Chlorophyll Equations for Acetone, Methanol and Ethanol Solvents. - Photosynthesis Research 89(1): 27-41. https://doi.org/10.1007/s11120-006-9065-9.

[50] Sand-Jensen, K., Pedersen, O., Binzer, T., Borum, J. (2005): Contrasting Oxygen Dynamics in the Freshwater Isoetid Lobelia dortmanna and the Marine Seagrass Zostera marina. - Annals of Botany 96(4): 613-623. https://doi.org/10.1093/aob/mci214.

[51] Science Framework Climate Working Group. (2016): Temperature (Mean: Annual) - 20202050 - RCP4.5 - Mean. - Science Framework Climate Working Group, Washington.

[52] Smith, V. H., Tilman, G. D., Nekola, J. C. (1999): Eutrophication: Impacts of excess nutrient inputs on freshwater, marine, and terrestrial ecosystems. - Environmental Pollution 100(1-3): 179-196. https://doi.org/10.1016/S0269-7491(99)00091-3.

[53] Somboonsuke, B., Phitthayaphinant, P., Sdoodee, S., Kongmanee, C. (2018): Farmers' perceptions of impacts of climate variability on agriculture and adaptation strategies in Songkhla Lake basin. - Kasetsart Journal of Social Sciences 39(2): 277-283. https://doi.org/10.1016/j.kjss.2018.05.006.

[54] Thongkao, S., Nintharakit, N., Pattanakiart, S. (2001): Pattern changes of aquatic plants in Ku Khud lake (Songkhla) during 1988-1996: A remote sensing study. - In: 5. BRT Annual Conference, Udon Thani (Thailand), 8-11 Oct 2001.

[55] Vitousek, P. M., Mooney, H. A., Lubchenco, J., Melillo, J. M. (1997): Human domination of Earth's ecosystems. - Science 277(5325): 494-499.

[56] Wigand, C., Wehr, J., Limburg, K., Gorham, B., Longergan, S., Findlay, S. (2000): Effect of Vallisneria americana (L.) on community structure and ecosystem function in lake mesocosms. - Hydrobiologia 418(1): 137-146. https://doi.org/10.1023/A:1003808220424.

[57] Yang, X., Wu, X., Hao, H., He, Z. (2008): Mechanisms and assessment of water eutrophication. - Journal of Zhejiang University SCIENCE B 9(3): 197-209. https://doi.org/10.1631/jzus.B0710626. 
[58] Zhang, P., Grutters, B. M. C., van Leeuwen, C. H. A., Xu, J., Petruzzella, A., van den Berg, R. F., Bakker, E. S. (2018): Effects of rising temperature on the growth, stoichiometry, and palatability of aquatic plants. - Frontier in Plant Sciences 2018: 01947. https://doi.org/10.3389/fpls.2018.01947. 